\title{
VYBRANÉ OTÁZKY ČESKÉHO PRÁVA SOCIÁLNÍHO ZABEZPEČENÍ JAKO PROINTEGRAČNÍHO NÁSTROJE ${ }^{1}$
}

\author{
MARTIN ŠTEFKO
}

\begin{abstract}
Selected Questions of the Czech Social Security Law as a Tool for Integration
To have employment remains to be one of the most effective ways of integration into Czech society. Employment is at the same time considered to be the most desired circumstance for establishing social insurance and health care insurance; it also simplifies access to welfare grants. To show the complex picture of Czech social security approaches towards foreigners, we have chosen to elaborate on miners' pensions and employers' liability for harm caused to workers in the course of work.
\end{abstract}

Keywords: social security; Integration; miners' benefits; employers' liability

Klíčová slova: sociální zabezpečení; integrace; hornické důchody; odpovědnost zaměstnavatele

DOI: $10.14712 / 23366478.2018 .6$

\section{ÚVOD}

Po demokratických změnách a vstupu do Evropské unie se zvýšila atraktivita České republiky, která se tak opět stala součástí široce chápaného demokratického Západu. ${ }^{2}$ Proto zvyšování počtu cizinců žijících legálně i nelegálně v českých zemích lze očekávat též v budoucnu, alespoň pokud jde o migrační proudy z východní Evropy. ${ }^{3}$

Obecně je pravdou, že pro integraci cizincủ je klíčový př́ístup na pracovní trh. Zaměstnání v pracovněprávním vztahu je rovněž českým právem sociálního zabezpečení považováno za rozhodující skutečnost, která zakládá účast nejen v sociálním a zdravotním pojištění, ale podstatně ulehčuje př́stup k nepojistným dávkám. Tento článek se nezabývá př́ímo ochranou pracovního trhu, analyzuje však dva vybrané instituty, které s př́istupem na český pracovní trh velmi úzce souvisí a spoluutváŕejí vztah cizince a majoritní společnosti. Po obecném úvodu (oddíl první) byly k hlubší analýze vybrány

1 Tento př́íspěvek vznikl díky finanční podpoře poskytované v rámci výzkumného projektu „Soukromé právo a výzvy dneška“, id. č. Q03.

2 HALÁSZ, I.: Mezinárodná migracia, krajania a volebné právo. Praha, 2012, s. 18.

3 Srov. TARAN, P. - IVAKHNYUK, I. - PEREIRA RAMOS, M. C. - TANNER, A.: Economic migration, social cohesion and development: towards an integrated approach. Štrasburk, 2009, s. 14 a 17. Podíl Ukrajinců na celkovém počtu ekonomicky aktivních cizinců v ČR se v r. 1995 blížil jedné čtvrtině, v r. 2005 se zvýšil již na $28 \%$. Srov. FRANC, A.: Hlavni tendence ve vývoji pracovnich migracív České republice. Brno, 2006, s. 15. 
hornické důchody (oddíl druhý) a specificky česká úprava odpovědnosti zaměstnavatele za újmu způsobené zaměstnanci pracovním úrazem či nemocí z povolání (oddíl třetí). Jestliže kauza hornických důchodů představuje pozitivní náborový nástroj pro nové horníky, a to právě za situace, kdy česká pracovní síla je v podstatě vyčerpána, v druhém př́padě se jedná o spíše negativní protiimigrační efekt. I horníci cizinci při výkonu svého povolání umírají či jsou zraněni, a pak se v plné míře ukážou koncepční problémy české úpravy. ${ }^{4}$

\section{VSTUPNÍ PřEHLED}

V rámci stručného úvodního přehledu budeme postupovat systematicky od sociálního pojištění (včetně veřejného zdravotního pojištění) ke státní sociální podpoře a sociální pomoci.

Osobní rozsah veřejného zdravotního pojištění je v národní úpravě spojen se získáním trvalého pobytu na území České republiky. Dále jsou na pojištění účastny osoby, které na území České republiky nemají trvalý pobyt, pokud jsou zaměstnanci zaměstnavatele, který má sídlo nebo trvalý pobyt na území České republiky. Zdravotní pojištění vzniká dnem narození, jde-li o osobu s trvalým pobytem na území České republiky; dnem, kdy se osoba bez trvalého pobytu na území České republiky stala zaměstnancem či dnem, kdy získala trvalý pobyt na území České republiky. ${ }^{5} \mathrm{Z}$ veřejného zdravotního pojištění jsou ex lege vyjmuti neohlášení migranti. Za cizince s povoleným trvalým pobytem se považují 6 též azylanti po dobu platnosti rozhodnutí o udělení azylu: ${ }^{7}$ osoby požívající doplňkové ochrany, ${ }^{8}$ cizinci poživající dočasné ochrany; ${ }^{9}$ držitelé platného povolení $\mathrm{k}$ dlouhodobému pobytu za účelem vědeckého výzkumu ${ }^{10} \mathrm{a}$ cizinci v některých dalších situacích. ${ }^{11}$

4 Srov. informaci Smrtelný pracovní úraz. Horník, 2018, č. 2, str. 1. či stejnou rubriku opět in Horník, 2017, č. 14 , str. 1 .

5 Ke konstrukci osobního rozsahu např. usnesení ÚS ze dne 24. 3. 2000, sp. zn. IV. ÚS 15/2000, kde Ústavní soud uvedl: „S takovým systémem lze zajisté polemizovat, rozhodně však jej nelze kvalifikovat jako neústavní jen proto, že se neslučuje s životní filosofii konkrétní osoby. Logika zákona, směrující k tomu, aby byly pokud možno vyloučeny nedobytné pohledávky poskytovatelů zdravotní péče za osobami nepojištěnými (což je běžný stav v zemich, které maji systém nepovinného smluvniho pojištění) je zřejmá, srozumitelná a nelze ji hodnotit jako svévoli či libovi̊li zákonodárce."

$6 \mathrm{~K}$ zavedení fikce trvalého pobytu došlo především z důvodu odlišných výkladů zákona č. 350/2005 Sb. K tomu KOSAŘ, D. - MOLEK, P. - HONUSKOVÁ, V. - JURMAN, V. - LUPAČOVÁ, H.: Zákon o azylu. Komentár. Praha, 2010, str. 503.

7 Srov. ust. § 76 zákona o azylu.

8 Srov. ust. § 53c zákona o azylu.

9 Srov. ust. § 32 zákona o dočasné ochraně cizinců.

10 Ust. § 42f odst. 5 zákona o pobytu cizinců.

11 Pobývá-li např. zákonný zástupce narozeného cizince na českém území na základě povolení k dlouhodobému pobytu nebo povolení k trvalému pobytu, je povinen ve lhůtě podat za narozeného cizince žádost o vydání povolení k dlouhodobému pobytu, nebo o udělení povolení k trvalému pobytu. V př́ípadě podání žádosti o povolení trvalého pobytu se pobyt narozeného cizince od okamžiku narození do právní moci rozhodnutí o této žádosti považuje za pobyt trvalý. 
Platná právní úprava nemocenského pojištění v zásadě nerozlišuje, zda zaměstnanec je občanem České republiky nebo jiného státu. ${ }^{12}$ To ale neznamená, že český systém je vůči občanům jiných států zcela neutrální. Český systém nemocenského pojištění vylučuje z veřejnoprávního nemocenského pojištění neohlášené cizince. V určitých okrajových př́padech obligatorně zahrnuje zaměstnance (tj. přiděluje dobro) do nemocenského a tím i důchodového pojištění dle dílčích kritérií jako je trvalý pobyt, ${ }^{13}$ podněcuje zaměstnavatele ke snížení obecné nemocnosti zaměstnanců, zatěžuje souhlasem orgánu nemocenského pojištění povolení změny místa pobytu dočasně práce neschopného pojištěnce do zahraničí, ${ }^{14}$ zdražuje výplatu dávek do zahraničí ${ }^{15}$ a speciálně upravuje doručování do zahraničí. ${ }^{16}$

České veřejnoprávní důchodové pojištění je systém dávkově definovaný, průběžně financovaný s vysokou mírou přerozdělování př́imů. Vzhledem k postavení občanů třetích států je nutno zdůraznit, že základním limitem zůstává získání potřebné doby pojištění. Pokud se vůči zaměstnanci neuplatní koordinační nařízení ani mezinárodní smlouva o sociálním zabezpečení, ${ }^{17}$ pak je nutno posuzovat nárok na dávky z českého důchodového systému dle českých právních předpisů, především zákona o důchodovém pojištění. ${ }^{18}$ Přiznání statusu uprchlíka či doplňkové ochrany samo o sobě nezakládá právo na jakákoliv zvýhodnění, pokud jde o splnění předpokladů pro nárok na dávku

12 Novelizace zákona o nemocenském pojištění s účinností k 1. 1. 1993 prolomila zákaz exportu dávek ku prospěchu zaměstnanců, kteří přechodně či trvale pracují v zahraničí, pokud se jim do ciziny vyplácena i mzda (plat). Další novelizace zákona o nemocenském pojištění s účinností k 1. 1. 1994 upravila, že dávky nemocenského pojištění náleží i za dobu, po kterou se oprávněný zdržuje v cizině trvale. Omezení však nadále platila pro podporu při narození dítěte a pohřebné, tyto dávky byly následně upraveny komplexně $\mathrm{v}$ rámci státní sociální podpory.

13 Ust. § 6 odst. 1 písm. a) bod 2 zákona o nemocenském pojištění.

14 Ust. $\$ 56$ odst. 3 in fine zákona o nemocenském pojištění.

15 Jedná se ovšem o pozitivní změnu oproti ust. § 51 zákona č. 54/1956 Sb., ve znění od 1. 1. 1995 do 31. 12. 2008. Dle této úpravy sice dávky nemocenského pojišsění náležely též za dobu, po kterou se oprávněný zdržoval trvale v cizině, nicméně do zahraničí se tyto dávky nevyplácely. Výjimka platila za předpokladu, že nemocenské pojištění prováděl zaměstnavatel pro zaměstnance, kteří vykonávali práci mimo území České republiky, dále pak pro zaměstnance zaměstnavatelů se sídlem na českém území, pokud měli místo výkonu práce trvale $\mathrm{v}$ cizině (pokud byli pojištěni podle tohoto zákona a měli trvalý pobyt na území České republiky). Výjimku dále mohlo povolit Ministerstvo práce a sociálních věcí ČR. Dávky dle platné úpravy se vyplácejí do zahraničí na základě žádosti pojištěnce, a to na účet pojištěnce u banky a za úhradu nákladů této výplaty. Více na: http://www.cssz.cz/cz/evropska-unie/nemocenske-pojisteni/vyplata-ceske -davky-do-zahranici.htm (Cit.: 10. 11. 2017).

16 Dle ust. § 149 odst. 4 zákona o nemocenském pojištění ustanoví orgán nemocenského pojištění v případě doručování do ciziny opatrovníka adresátům, kteří se zdržují v cizině nebo jejichž pobyt nebo sídlo, poprŕípadě jiná adresa pro doručování je $\mathrm{v}$ cizině, pokud se jedná o písemnost ve věcech dávek, př̌platku na dávce nebo regresní náhrady.

17 Zde se podotýká, že se Sýrí́ byla vyjednána a posléze v roce 2010 též podepsána smlouva o sociálním zabezpečení. Smlouva byla schválena oběma komorami Parlamentu ČR, zatím však nedošlo k její ratifikaci.

18 Zvláštní úprava tzv. dílčení je obsažena v ust. § 66 zákona o důchodovém pojištění. Dle předmětné úpravy platí, že osobám, které nemají na území České republiky trvalý pobyt nebo které se na území České republiky obvykle nezdržují, se vyplácí důchod ve výši odpovídající době pojištění (včetně doby výdělečné činnosti získané v zahraničí, pokud za ni bylo do českého systému zaplaceno pojistné) a náhradní době pojištění získaným na území České republiky. Za osoby, které se na území České republiky obvykle nezdržují, se považují osoby, které v zahraničí pobývají v kalendářním roce po dobu alespoň 270 dnů. Tato úprava se uplatní bez zřetele, jak je důchod vyplácen. Srov. PŘIB, J. - VOŘÍŠEK, V.: Dưchodové predpisy s komentářem. Praha, 2012, str. 275. 
důchodového pojištění, či v rámci ř́zení o její přiznání. Pokud již bylo politicky rozhodnuto o zvýhodněném postupu, pak se tak dělo mimo zákon o asylu príímo akty ř́zení. ${ }^{19}$

Česká republika poskytuje pomoc ${ }^{20}$ rodinám s dětmi především prostřednictvím systému státní sociální podpory, který je zcela financován ze státního rozpočtu. V jeho rámci je také částečně řešena finanční podpora bydlení. Na dávky státní sociální podpory může vzniknout nárok též cizím státním př́slušníkům. U cizinců je ovšem vyžadováno povolení trvalého pobytu a bydliště na území České republiky. ${ }^{21}$ Za trvalý pobyt se přitom ale považuje též jiný hlášený pobyt cizince, a to ode dne, kterým uplynulo 365 dnů ode dne hlášení. ${ }^{22}$ Podmínku splnění předchozí čekací doby nemusí splňovat malé děti, cizinci do 1 roku jejich věku, kteří se na území České republiky narodili a jsou zde též hlášeni k pobytu. ${ }^{23}$ Tuto podmínku nemusí splňovat dále též některé další kategorie cizinců vymezené v ust. § 3 zákona o státní sociální podpoře.

Právní úprava sociální pomoci omezuje právo na pomoc, které v Ústavě v zásadě českou státní př́slušností limitováno není. ${ }^{24}$ Pouze na bezplatné poskytnutí základního sociálního poradenství o možnostech řešení nepříznivé sociální situace nebo jejího předcházení má nárok každá osoba (ust. § 1 odst. 2 zákona o pomoci v hmotné nouzi a dále ust. $\S 2$ odst. 1 zákona o sociálních službách). ${ }^{25}$ Př́ístup k dávkám hmotné nouze, př́spěvku na živobytí, doplatku na bydlení, ${ }^{26}$ stejně jako k př́spěvku na péči ${ }^{27}$ poskytovaném dle zákona č. 108/2006 sb., o sociálních službách, v platném znění, a k právu

19 Srov. Usnesení vlády ze dne 1. listopadu 2006 č. 1248 k Postupu při dokončení přesídlení osob s prokázaným českým původem (krajanů) z Kazachstánu.

20 K subsidiaritě systému zejména rozhodnutí NSS č.j. 5 A 74/2000-37 a dále usnesení ÚS sp. zn. IV ÚS 497/09 a recentní IV. ÚS 1148/10.

21 Ministerstvo práce a sociálních věcí může v odůvodněných případech prominout podmínku trvalého pobytu. Rozhodnutí ministerstva je ovšem vyloučeno ze soudního přezkumu.

22 Do doby 365 dnů se ovšem nezapočítává doba pobytu žadatelů o udělení mezinárodní ochrany ve střediscích Ministerstva vnitra.

23 Problém ovšem nastává po uplynutí prvního roku věku dítěte, nebot' rodiče dítě obvykle nepřihlásí v den narození. Srov. ust. § 93 zákona o pobytu cizinců. K tomuto problému blíže BŘESKÁ, N. - BURDOVÁ, E. - KEPKOVÁ, M. - VRÁNOVÁ, L.: Státni sociálni podpora s komentářem a príklady. Praha, 2012, str. 21 a násl.

24 Opět ovšem ve shodě s unijní úpravou, srov. např. čl. 15 odst. 2 písm. a) směrnice č. 2003/109/ES nebo čl. 7 odst. 1 písm. c) směrnice č. 2003/86/ES.

25 Důvodová zpráva tento postup odůvodňuje čl. 13 Evropské sociální charty a ochrany společnosti před vznikem a šířením nežádoucích společenských jevů. Důvodová zpráva, zvláštní část, komentář k ust. § 4, PSP ČR, 2005, tisk 1102/0.

26 Jestliže po úhradě odůvodněných nákladů na bydlení (společně s př́íspěvkem na bydlení) je př́ijem oprávněné osoby a s ní společně posuzovaných osob nižší, než částka jeho živobytí vzniká rodině nárok na doplatek na bydlení. Výše doplatku na bydlení je stanovena tak, aby po zaplacení odůvodněných nákladů na bydlení (tj. nájmu, služeb s bydlením spojených a nákladů za dodávku energií) zůstala oprávněné osobě a s ní společně posuzovaným osobám částka živobytí. Pokud některá ze společně posuzovaných osob není oprávněnou osobou, stanoví se výše doplatku na bydlení s poměrnou částí prríspěvku připadajícího na tuto osobu, nebot' příspěvek na živobytí je v takovém případě stanoven bez poměrné části příspěvku připadající na tuto osobu.

27 Př́spěvek na péči se poskytuje osobám závislým na pomoci jiné fyzické osoby za účelem zajištění potřebné pomoci. Osoba se považuje za závislou na pomoci jiné fyzické osoby ve stupni I (lehká závislost), stupni II (středně těžká závislost), stupni III (těžká závislost) nebo stupni IV (úplná závislost). O příspěvku rozhoduje krajská pobočka Úřadu práce ČR. 
na poskytnutí většiny sociálních služeb není sice podmíněn státní příslušností k České republice, není však též personálně neomezený. ${ }^{28}$

\section{ZVÝHODNĚNÁ SKUPINA POJIŠTĚNCŮ - HORNICKÉ DŮCHODY}

Těžba nerostů v hlubinném hornictví je velmi rizikové povolání. Zdravotní náročnost, expozice a relativně nižší finanční ohodnocení jsou hlavní důvody, které již dř́ve vedly k tomu, že se průběžně snižoval počet horníků české státní příslušnosti ve prospěch občanů Slovenska, Polska a dalších států, jako např. Ukrajiny a Ruska. ${ }^{29}$ Tento trend pochopitelně pokračuje i nadále, k čemuž mimo jiné přispělo snížení důchodového věku. Na tomto místě ovšem budeme analyzovat racionálnost této specifické úpravy z hlediska skutečného působení na cizí státní př́slušníky.

Zvýhodnění horníků spočívá ve dvou oblastech: ve snížení důchodového věku a ve změnách při výpočtu dávky. Jestliže ratio legis snížení důchodového věku je poměrně jasné - pracovně těžko uplatnitelní horníci odejdou na zasloužený odpočinek, uvolní pracovní místa a současně při obecně nižší pravděpodobnosti věku dožití si dříve užijí zasloužený odpočinek, zvýhodnění při výpočtu výše důchodu je zdůvodnitelné hůře, protože ve skutečnosti exponenciálně zvyšuje rozdíly mezi ostatními pojištěnci a horníky.

Obě výhody mají svůj původ v předlistopadové úpravě a jejich přežití do současnosti je výsledkem působení více faktorů. Startovacím impulzem byla však zřejmě prioritně výše důchodového věku. Zrušení pracovních kategorií zákonem č. 235/1992 Sb. bylo považováno za nepřiměřenou tvrdost pro relativně malý okruh zaměstnanců; pro ty pracovníky, kterým k dosažení důchodového věku podle předchozích předpisů, chyběla doba od jednoho do pěti let. Následně se ovšem výjimky rozšiřovaly tak široce až se nakonec výjimky staly pravidlem a konstituovaly novodobou privilegovanou kategorii pojištěnců.

Na základě tlaku Odborového svazu pracovníků hornictví, geologie a naftového průmyslu, jakož i pod vlivem situace v OKD, a.s. (hrozba uzavření dolu Paskov) ${ }^{30}$ bylo nakonec bez důkladné analýzy právní úpravy přijato nařízení č. 363/2009 Sb., které umožnilo vztáhnout dosud existující výhody na větší okruh horníků. I když cílem těchto výjimek bylo prioritně postihnout pojištěnce, kteří započali s výkonem činnosti v době existence pracovních kategorií, k doplnění potřebného počtu směn již díky těmto výjimkám mohlo dojít až do 31. 12. 2008. To ve svém důsledku znamená faktické prodloužení existence pracovních kategorií a tím pádem dřívějších odchodů do důchodu, nebot' celá doba potřebná pro zahrnutí do přechodných opatření mohla být získána až

28 Srov. rozsudek NSS ze dne 14. 12. 2011, č. j. 6 Ads 128/2011-55.

29 Srov. informaci Rubání v DZ 1 bojovaly s př́rodou i úbytkem horníků. Horník, 2017, č. 13, str. 2; Polští horníci z Room \& Pillar vyhráli soutěž BOZP už potřetí. Hornik, 2017, č. 9, str. 3; informaci OKD začne hledat dlouhodobě nedostatkové kvalifikované profese na českém trhu práce. Horník, 2017, č. 3, str. 1; Práce v OKD stále táhne, zájem už projevily tři stovky lidí. Horník, 2017, č. 7, str. 2; či W styczniu w ZG Nr 3 miała największy urobek brygada ze spółki Alpex. Horník, 2016, č. 8, str. 9.

30 Připomínky Ministerstva financí v přípise č.j. MF-67951/2014/1401. 
po zrušení pracovních kategorií ${ }^{31}$ Definitivní průlom do snahy odbourat preferované kategorie zaměstnání pak znamená nařízení vlády č. 69/2015 Sb., kterým bylo umožněno získat potřebnou dobu i po roce 2008. Původní snížení důchodového věku pak bylo díky poslaneckému pozměňovacímu návrhu Romana Sklenáka zvýšeno z pěti na sedm let zákonem č. 213/2016 Sb. (dále „Reforma 2016“).

Pokud se jedná o výši hornických důchodů, pak je nutno konstatovat, že zde Reforma 2016 pouze navázala na již existující praxi. $Z$ celé řady podpůrných opatření lze zmínit situaci kolem novely zákona o důchodovém pojištění č. 188/2001 Sb. Novelou došlo ke zvýšení pouze mimořádných ( $\mathrm{tj}$. některých) hornických důchodů, negativní ohlas však nakonec donutil vládu formou odstranění tvrdosti zákona toto omezení podstatně zeslabit, a to v masových akcích realizovaných v letech 2004, 2005 a 2008.32 Ještě významnější byla ovšem novela provedená zákonem č. 264/2006 Sb., který v podstatě zavedl jednotnou dávku pro velmi široký okruh beneficientů. Jak vypočetla S. Švehláková, díky této novele je poskytována stejná dávka „hornickým“ pojištěncům, jejichž výpočtový základ se nachází v neuveřritelném rozmezí od 8720 Kč do 22690 Kč. Dalším opatřením bylo nařízení č. 363/2009 Sb., kterým došlo ke zvýšení hornických důchodů dvojím způsobem. Jednak šlo o zvýšení důchodu o všechny valorizace přiznané od roku 1996, jednak tím, že došlo i zpětně ke snížení důchodového věku, došlo ke zvýšení důchodu díky zhodnocení doby pojištění dle ust. $§ 34$ odst. 2 zákona o důchodovém pojištění, tedy za každých 90 odpracovaných kalendářních dní o 1,5 \% procentní výměry. Nařízení vlády č. 69/2015 Sb. a definitivně pak Reforma 2016 odbouralo zbývající náznaky zrušení pracovních kategorií a navíc otevřelo možnost př́ístupu ke zvýhodněným hornickým důchodům všem horníkům (bez ohledu na státní příslušnost), kteří konali tuto činnost př̀ed 1. ř́ijnem 2016.

Snížení důchodového věku a v podstatě paušální (a velmi výhodná) výše dávky nejsou limitovány ani státní př́slušností, ani trvalým pobytem. Pokud cizí státní př́slušník splnil stanovené podmínky, bude mu náležet tzv. hornický důchod dle Reformy 2016. Výhrady lze mít pouze u nových horníků - cizích státních př́slušníků. Zde se totiž již uplatní limit započetí s výkonem hornické činnosti před 1. ř́inem 2016. Cizí státní příslušníci, kteří budou muset nahradit dosluhující české horníky, tak budou svou prací financovat výhody, jež jsou jim odepřeny. Stejné pravidlo ovšem platí též u českých, moravských a slezských horníků. Proto lze očekávat, že při některé z následujících krizí útlumu těžby odbory opět využijí situaci k prolomení hranice 1. ř́ijna 2016.

31 Na rozdíl od pojištěnců, kterým k získání potřebné doby pojištění ovšem scházel období od jednoho do pěti let (a kterým byl důchodový věk stanoven na 55 let a 6 měsíců), u ostatních pojištěnců již byl důchodový věk snížen jen o pět let oproti obecnému důchodovému věku dle ust. §32 zákona o důchodovém pojištění. Separátní problém pak je zrušení povinné evidence odpracovaných směn. Více k tomu ŠVEHLÁKOVÁ, S.: Analýza změn českého systému drichodového pojištěni ve vztahu k zvýhodňovaným skupinám pojištěncủ. Diplomová práce. Brno, 2013, s. 13 a 14.

32 Srov. Př́ikaz ministra práce a sociálních věcí č. 27/2003. 


\section{HMOTNÉ ZABEZPEČENÍ PRO PŘÍPAD NEMOCI Z POVOLÁNÍ ČI PRACOVNÍHO ÚRAZU}

Zabezpečení zaměstnance pro př́ípad nemoci z povolání či pracovního úrazu není v České republice stále řešeno prostřednictvím úrazového pojištění, ale pracovněprávní úpravou odpovědnosti zaměstnavatele za škodu. ${ }^{33}$ Jedná se o institut objektivní odpovědnosti zaměstnavatele za výsledek - za poškození zdraví (škodu), které zaměstnanec utrpěl př̀i plnění pracovních úkolů nebo v přímé souvislosti s ním. Zaměstnavatel odpovídá i v případě, že škodu způsobila jiná osoba a též v případě, že škodu nezavinil. Zaměstnanci, který utrpěl pracovní úraz nebo u něhož byla zjištěna nemoc z povolání, je zaměstnavatel v rozsahu, ve kterém za škodu odpovídá, povinen poskytnout náhradu za ztrátu na výdělku, bolest a ztížení společenského uplatnění, účelně vynaložené náklady spojené s léčením a př́padně též věcnou škodu. Zemře-li zaměstnanec následkem pracovního úrazu nebo nemoci z povolání, je zaměstnavatel povinen $v$ rozsahu své odpovědnosti poskytnout: náhradu účelně vynaložených nákladů spojených $\mathrm{s}$ jeho léčením, přiměřených nákladů spojených s pohřbem, nákladů na výživu pozůstalých, jednorázové odškodnění pozůstalých a eventuálně též náhradu věcné škody.

Předmětná právní úprava byla po sovětském vzoru zavedena prakticky od počátku 60. let minulého století a nezměnila se ani s príijetím nového zákoníku práce. V současné době přitom již neodpovídá zásadním změnám ve společnosti a národním hospodářství, $\mathrm{k}$ nimž došlo od té doby. ${ }^{34} \mathrm{~S}$ účinností od 1. 1.1993 bylo sice zavedeno zákonné pojištění zaměstnavatele za škodu vzniklou zaměstnanci pracovním úrazem nebo nemocí z povolání, toto (tehdy deklarované) dočasné opatření však problém pouze zmírnilo, nikoliv vyřešilo. Nedostatky platné úpravy se bohužel ještě více zvýrazňují u občanů třetích států. Ač se na první pohled jedná o úpravu neutrální, nebot nároky poškozeného zaměstnance nejsou závislé na jeho státní př́ślušnosti či bydlišti na českém území, v praxi tento systém odrazuje občany třetích států od uplatňování jejich nároků na náhradu škody. To je nespravedlivé zejména proto, že právě občané třetích států obvykle konají práce zdravotně závadné či př́mo rizikové.

Základním problémem je přímé zapojení zaměstnavatele do procesu oznamování, resp. uplatňování nároku na náhradu škody. Cizinec je totiž povinen o náhradu škody žádat $\mathrm{u} /$ prostřednictvím zaměstnavatele. Je pochopitelné, že zaměstnavatel, u něhož k pracovnímu úrazu došlo, je povinen objasnit př́ćiny a okolnosti vzniku tohoto úrazu (ust. § 105 odst. 1 zákoníku práce), zaměstnavatel však současně má být dle české úpravy též tím, kdo by měl poškozenému zaměstnanci být nápomocen při uplatňování náhrady škody vůči jemu samému. Zaměstnanec, ale často ani zaměstnavatel přitom

33 Zákon č. 266/2006 Sb., o úrazovém pojištění, účinnosti ve většině svých ustanovení nenabyl (srov. ust. $\S 99$ cit. zákona) a dle rozhodnutí vlády se tomu ani v budoucnu tak nestane. Tak např. vyjádření ministra zdravotnictví: http://www.psp.cz/eknih/2010ps/stenprot/040schuz/s040304.htm (Cit.: 6.11.2017). K akcím na půdě Parlamentu ČR např.: http://www.parlamentnilisty.cz/arena/monitor/Snemovna-schvalila-zruseni -zakona-o-urazovem-pojisteni-247181 (Cit.: 7.11.2017) a zde: http://www.opojisteni.cz/ekonomika/vyvoj -trhu/klaus-souhlasil-s-odlozenim-zakona-o-urazovem-pojisteni-zamestnancu/ (Cit.: 21.10.2017).

34 Srov. NOVOTNÝ, Z. In BĚLINA, M. - DRÁPAL, L. a kol.: Zákoník práce. Komentář. Praha, 2012, str. 1377. 
nerozlišují mezi tím, komu je nutno škodní událost nahlásit a tím, kdo potenciální nárok na náhradu škody uhradí (zaměstnavatelé s výjimkou státu jsou pro tyto účely ze zákona pojištěni). Navíc opožděné oznámení pracovního úrazu př́slušným institucím ${ }^{35}$ či zjištění porušení bezpečnostních předpisư ${ }^{36}$ mají nutně za následek sankci pro zaměstnavatele. Proto se nelze divit, že zaměstnavatelé obvykle nejsou př́liš vstřícní a žádosti poškozených občanů třetích států nepodporují.

Vedle obavy ze ztráty zaměstnání pro domáhání se svých práv je zde ovšem další klíčová limitace potenciální náhrady škody, která je zapracována do základů platné právní úpravy. Jedná se o sjednanou omezenou délku pracovněprávního vztahu, která je právě u této kategorie zaměstnanců pravidlem. Dle ust. $\$ 386$ odst. 1 věta první zákoníku práce platí: „Zaměstnanci, který utrpí (...) v pracovním poměru sjednaném na dobu určitou nebo při výkonu práce na základè dohody o pracovní činnosti uzavřené na dobu určitou, př́sluši náhrada za ztrátu na výdělku jen do doby, kdy měl tento pracovněprávni vztah skončit. Po této době př́sluši náhrada za ztrátu na výdělku, jestliže je možné podle okolností předpokládat, že postižený by byl i nadále zaměstnán. "Předmětná úprava reguluje sice pouze jeden z nároků poškozeného zaměstnance, obvykle se ovšem jedná o ten finančně nejnáročnější. Cílem této úpravy je omezit tento nárok u zaměstnanců, kteří vykonávají výdělečnou činnost jen občas, nebo kteří nemají výdělečnou činnost jako hlavní (základní) zdroj svých př́ijmů, a proto uzavřeli pracovní poměr na dobu určitou jen př́ležitostně a po uplynutí sjednané doby by nadále nepracovali v pracovním poměru, i kdyby k pracovnímu úrazu nedošlo. Z tohoto důvodu je nutno zde zařadit též zaměstnance konající práci na základě dohody o provedení práce, byt' tento typ pracovněprávního vztahu ZP explicitně nezmiňuje. Jinak by došlo k absurdní situaci, kdy zaměstnanci pracující z kvantitativního hlediska potenciálně nejkratší množství pracovních hodin by požívali vyšší jistoty, než zaměstnanci pracující na základě pracovního poměru na dobu určitou či pracovněprávního vztahu založeného dohodou o pracovní činnosti.

Ke skončení pracovního poměru či jiného pracovněprávního vztahu sjednaného na dobu určitou dojde bez ohledu na situaci, v níž se zaměstnanec nachází. Nárok občana třetího státu na náhradu za ztrátu na výdělku je $\mathrm{v}$ takovém prŕpadě podmíněn prokázáním, že nebýt tohoto pracovního úrazu či nemoci z povolání, pak by byl dále zaměstnán. To je ovšem k sekundární povaze zaměstnání, tj. nutnosti provádět test pracovního trhu před prodloužením či novým udělením povolení k zaměstnání, obzvláště obtížné. Stávající judikatura Nejvyššího soudu nabízí i v tomto směru určitý prostor. Nárok na náhradu za ztrátu na výdělku vznikne též v př́ípadě, kdy další zaměstnávání občana

35 Srov. ust. § 4 nařízení vlády č. 201/2010 Sb., o způsobu evidence úrazů, hlášení a zasílání záznamu o úrazu.

36 Tak např. právo pojišt’ovny na regres vůči zaměstnavateli dle ust. § 10 odst. 1 písm. b) vyhlášky č. 125/1993 Sb., kterou se stanoví podmínky a sazby zákonného pojištění odpovědnosti zaměstnavatele za škodu při pracovním úrazu nebo nemoci z povolání. Další sankcí je přirážka k pojistnému ze strany př́íslušné zdravotní pojištovny (ust. § 45 zákona č. 48/1997 Sb., ve znění do 31. 12. 2014) či okresní správy sociálního zabezpečení, resp. PSSZ nebo MSSZ Brno (dle ust. § 21 zákona č. 592/1992 Sb., ve znění do 31. 12. 2014). v neposlední řadě se jedná o sankci za správní delikty na bezpečnosti práce (ust. § 30 zákona o inspekci práce), bezpečnosti technických zařízení se zvýšenou mírou ohrožení života a zdraví (ust. § 32 zákona o inspekci práce) či na úseku vyhrazených technických zařízení (ust. § 33 zákona o inspekci práce). 
třetího státu lze podle okolností jen předpokládat. ${ }^{37}$ Důvodný předpoklad lze nabýt pouze s přihlédnutím $\mathrm{k}$ okolnostem, které tu byly $\mathrm{v}$ době úrazu a které vypovídají o tom, zda zaměstnanec uzavřel pracovněprávní vztah na dobu určitou jen př́iležitostně (a po uplynutí sjednané doby trvání pracovního poměru by stejně nadále nepracoval), nebo zda hlavním (základním) zdrojem jeho příjmů byla výdělečná činnost a zaměstnanec do té doby pravidelně pracoval (a lze tedy podle okolností předpokládat, že po skončení pracovního poměru by byl znovu zaměstnán). „Když se pracovníkovi podaři tuto skutečnost prokázat, lze přiznat náhradu za ztrátu na výdèlku do výše prüměrného výdèlku, který dosahoval natrvalo u organizace, u niž utrpèl pracovní úraz."38

Další omezení jsou pak již společná s dalšími poškozenými - občany České republiky. Zaměstnanec obvykle není schopen prokázat existenci prŕćinné souvislosti mezi pracovním úrazem a vznikem škody. To je dáno obvykle důvodem skončení pracovního poměru, kterým bude (neskončí-li uplynutím sjednané doby) jiný výpovědní důvod, než zákaz dále konat dosavadní práci pro pracovní úraz či onemocnění nemocí z povolání dle lékařského posudku vydaného poskytovatelem pracovnělékařských služeb nebo rozhodnutí př́slušného správního orgánu, který lékařský posudek přezkoumává. Zaměstnanec $\mathrm{v}$ těchto př́padech včas nenapadne neplatnost rozvázání pracovního poměru u soudu, což má za následek následnou nemožnost přezkumu právního úkonu končícího pracovněprávní vztah. ${ }^{39}$ Podaří-li se neplatnost včas napadnout, pak soud při zkoumání příčin ztráty na výdělku zaměstnance obligatorně vychází z lékařského posudku vydaného poskytovatelem pracovnělékařských služeb nebo rozhodnutí př́islušného správního orgánu, který lékařský posudek přezkoumává, i když převedení zaměstnance na jinou práci nebo rozvázání pracovního poměru bylo odůvodněno jinými skutečnostmi (skutečnostmi, které nemají původ v nemoci z povolání). ${ }^{40}$

Výrazným limitem je obtížnost prokázání výše ušlého výdělku. V souladu s platnou judikaturou nelze při stanovení průměrného výdělku před vznikem škody vycházet z př́ijmů, které poškozený pobíral od bývalého zaměstnavatele, pokud jde o nárok na náhradu za ztrátu na výdělku po skončení pracovní neschopnosti až poté, kdy pracovní poměr poškozeného zaměstnance u zaměstnavatele, který mu za škodu odpovídá, skončil z jiných důvodů než pro následky pracovního úrazu. Nejvyšší soud rozhodl, že v prŕíčinné souvislosti s pracovním úrazem je v takovém př́ípadě taková ztráta na výdělku, která vychází z průměrného výdělku, jehož by poškozený zaměstnanec prokazatelně dosáhl u jiného zaměstnavatele za práci, kterou by pro něj vykonal, kdyby k pracovnímu úrazu nedošlo. ${ }^{41}$ Poškozený zaměstnanec je pak v podstatě nucen prokázat, kolik by dostal za práci konanou pro jiného zaměstnavatele zaplaceno, kdyby nebyl postižen pracovním

37 Srov. rozsudek NS ze dne 6. 6. 2006 sp. zn. 21 Cdo 2023/2005.

38 Zhodnocení NS ČSR ze dne 27. 1. 1975, sp. zn. Cpj 37/74 (R 11/1976, str. 51-52).

39 Tak např. Stanovisko NS ČSR ze dne 12. 3. 1987, sp. zn. Cpj 291/86 (R 20/1987/II). Jedná se přitom o lhůtu hmotněprávní a prekluzivní. Žalobce dohodu o rozvázání pracovního poměru v této lhůtě u soudu nenapadl. Proto se žalovaný dovolává Stanoviska NS ČSR ze dne 12. 3. 1987, sp. zn. Cpj 291/86 (R 20/1987/ III), které jednoznačně konstatovalo: „Jestliže žaloba o neplatnost rozvázání pracovního poméru dohodou nebyla podána ve lhůtě stanovené § $64 \mathrm{ZPr} 1965$, skončil pracovní pomèr dohodou účastnikủ o jeho rozvázání. Platnost rozvázání pracovniho poměru dohodou nemůže být soudem později posuzována."

40 Rozsudek NS ze dne 20. 3. 2003, sp. zn. 21 Cdo 1199/2002 (SJ 60/2003).

41 Tak rozsudek NS ze dne 10. 12. 2002, sp. zn. 21 Cdo 1185/2002 (R 64/2003). 
úrazem či nemocí z povolání. Výrazně jednodušší je situace, pokud se poškozený zaměstnanec stane uchazečem o zaměstnání. $V$ takovém př́ípadě se ze zákona za výdělek po pracovním úrazu nebo po zjištění nemoci z povolání považuje výdělek ve výši minimální mzdy. Pobíral-li ovšem zaměstnanec před tím, než se stal uchazečem o zaměstnání, náhradu za ztrátu na výdělku po skončení pracovní neschopnosti, př́isluší mu tato náhrada v takové výši, ve které mu na ni vzniklo právo za trvání pracovního poměru.

\section{ZÁVĚR}

Pokud se jedná o situaci v České republice pak jednoznačnou oporu pro tvrzení o chybném (tj. restriktivním) nasměrování stávající sociální politiky dává stav českého trhu práce, očekávaný demografický vývoj české společnosti a fenomén neohlášených cizinců. Jistě není třeba dodávat, že všechny tyto faktory mají mimořádný význam pro české hospodářství i pro financování výdobytků sociální politiky.

Český systém veřejnoprávního důchodového pojiššení je moderním systémem sociálního pojištění, který díky vysoké míře intergenerační i intragenerační solidarity, omezení zásluhovosti u vyšších př́ijmových skupin pojištěnců a dynamičnosti je systémem dlouhodobě udržitelným. Největším rizikem pro jeho fungování nejsou z povahy věci migrační vlny, ale nerozvážná rozhodnutí domácích politických elit. Ta ovšem nejsou motivována snahou zvýhodnit žadatele o azyl, uprchlíky či snad osoby, kterým bude přiznána jistá forma mezinárodní ochrany, ale podléhají lokálním lobbistickým tlakům.

$\mathrm{Z}$ důchodového pojištění sice může a je zabezpečována určitá skupina přesídlených krajanů z východní Evropy, toto řešení se však neukázalo jako vhodné a nebude s největší pravděpodobností opakováno. Nedojde-li ke specifickému zvýhodnění uprchlíka či osoby, které je přiznána mezinárodní ochrana, pak tato obvykle vzhledem ke své odlišné ekonomické historii nárokovat dávky z důchodového pojištění pro nesplňování předpokladů nemůže. To ovšem není nic mimořádného, nebot' k řešení sociálních rizik ohrožujících migranty jsou určeny jiné subsystémy práva sociálního zabezpečení. Důchodové pojištění včetně hornických specifik zůstává dlouhodobým sociálním pojištěním, které může obdařit dobrodiním ty pojištěnce, kteří se ho účastní v podstatě po celou svou profesní kariéru. Exces u hornických důchodů nebyl a není prioritně zacílen na cizince, výhody prosazené českými odborovými předáky však mohou velmi dobře využít soukromí vlastníci dolů právě při náboru cizinců na tuto nelehkou práci. Dočasnou nevýhodou je limitace snížení důchodového věku 1. ř́ijnem 2016, tento limit se však aplikuje též na české horníky.

Pokud zákonodárce již umožnil nelegálním migrantům sjednávat platně pracovněprávní vztahy, neměl by tolerovat, aby se potenciální riziko (např. pokles př́ijmů pro pracovní úraz, nemoc z povolání či invalidita) s tím spojené znásobovalo vyloučením těchto zaměstnanců z veřejnoprávních systémů sociálního pojištění. Nezbytná je vzhledem $\mathrm{k}$ povaze nelegální práce ${ }^{42}$ především účast $\mathrm{v}$ zákonném pojištění odpovědnosti

42 Nelegální migranti vykonávají na území České republiky především nekvalifikovanou práci, pro jejíž výkon není potřeba žádná či pouze minimální kvalifikace. Typicky se jednalo o mytí nádobí, úklid, pomocná pracovní síla, dělník v potravinářském průmyslu, stavebnictví, svářeč, betonář, obráběč kovů. Nelegál- 
zaměstnavatele za škodu při pracovním úrazu nebo nemoci z povolání (budoucím úrazovém pojištění). Vzorem pro př́slušnou úpravu v zákonech práva sociálního zabezpečení by mohla být např. úprava obsažená v ust. § 110 odst. 1 SGB VII. Dle předmětného ustanovení je zaměstnavatel povinen mimo jiné uhradit náklady vzniklé nositeli úrazového pojištění v souvislosti s pojistnou událostí ( $\mathrm{tj}$. např. pracovním úrazem při výkonu nelegální práce) i v př́ípadě, že nelegální zaměstnance nepřihlásil k pojištění, resp. za ně neodvedl stanovené pojistné. Neodvedení pojistného se presumuje v př́padě, že zaměstnanec nebyl u př́slušného nositele pojišstění zaregistrován. ${ }^{43}$

Bude-li politická vůle pak by ovšem jisté reformní kroky podniknuty být měly. Především by mělo být umožněno vyvést $\mathrm{z}$ důchodového pojištění pojistné zaplacené pojištěncem (občanem třetího státu), který nesplnil stanovené podmínky nároku na dávku důchodového pojištění z českého systému.

doc. JUDr. Martin Štefko, Ph.D.

Právnická fakulta Univerzity Karlovy

stefkom@prf.cuni.cz

ní zaměstnance využívali zaměstnavatelé ve stavebnictví, lesnictví, zahradnictví, zemědělství, obchodu a službách (hlavně tzv. osobní služby), pohostinství, textilním průmyslu, potravinářském průmysl, strojírenství, v dolech a hutích. Srov. KROUPA, A. a kol.: Nelegální zaméstnávání a podnikání cizinců na českém trhu práce. Praha, 1997. Publikace dostupná na: http://www.vupsv.cz/neleg.pdf (Cit.: 15.6.2010); HORÁKOVÁ, M.: Cizinci na trhu práce v České republice v letech 1994-2004. Praha, 2005.

43 Je nutno ovšem přiznat, že též tato úprava působí v praxi celou řadu problémů. Tak především preventivní význam této úpravy je výrazně omezen skutečností, že zaměstnavatel je povinen odvádět pojistné na úrazové pojištění zpětně. Předmětné ustanovení je dále omezeno jen na zaměstnavatele, kteří umožní výkon nelegální práce s cílem poskytovat služby či výrobky třetím osobám, nikoliv na zaměstnavatele, kteří využívají práce nelegálních migrantů pro své osobní potřeby. Srov. GIESEN, R.: Der Regress des Unfallversicherungsträger bei Schwarzarbeit nach 110 Abs. 1 a SGB VII. In LEINEMANN, W. - DÜWELL, F. J. - STÜCKEMANN, W. - WAGNER, V. (eds.): Bewegtes Arbeitsrecht. Festschrift für Wolfgang Leinemann zum 70. Geburtstag. Neuwied, 2006, str. 839 a 840. 